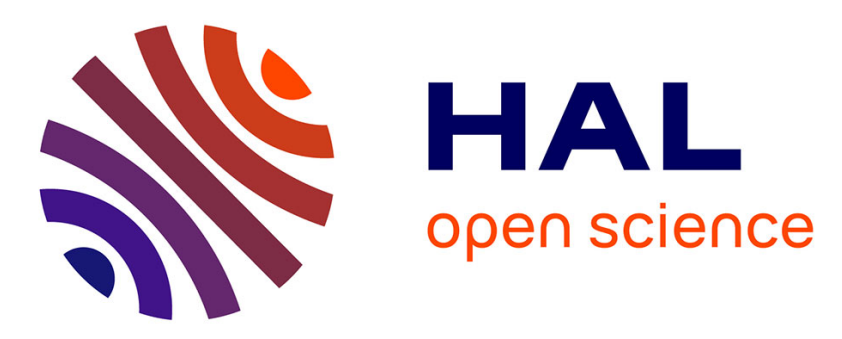

\title{
Marine Aggregates Facilitate Ingestion of Nanoparticles by Suspension-Feeding Bivalves
}

\author{
J. Evan Ward, Dustin J. Kach
}

\section{To cite this version:}

J. Evan Ward, Dustin J. Kach. Marine Aggregates Facilitate Ingestion of Nanoparticles by Suspension-Feeding Bivalves. Marine Environmental Research, 2009, 68 (3), pp.137. 10.1016/j.marenvres.2009.05.002 . hal-00563080

\section{HAL Id: hal-00563080 \\ https://hal.science/hal-00563080}

Submitted on 4 Feb 2011

HAL is a multi-disciplinary open access archive for the deposit and dissemination of scientific research documents, whether they are published or not. The documents may come from teaching and research institutions in France or abroad, or from public or private research centers.
L'archive ouverte pluridisciplinaire HAL, est destinée au dépôt et à la diffusion de documents scientifiques de niveau recherche, publiés ou non, émanant des établissements d'enseignement et de recherche français ou étrangers, des laboratoires publics ou privés. 


\section{Accepted Manuscript}

Marine Aggregates Facilitate Ingestion of Nanoparticles by Suspension-Feeding

Bivalves

J. Evan Ward, Dustin J. Kach

PII:

S0141-1136(09)00062-2

DOI:

10.1016/j.marenvres.2009.05.002

Reference:

MERE 3339

To appear in:

Marine Environmental Research

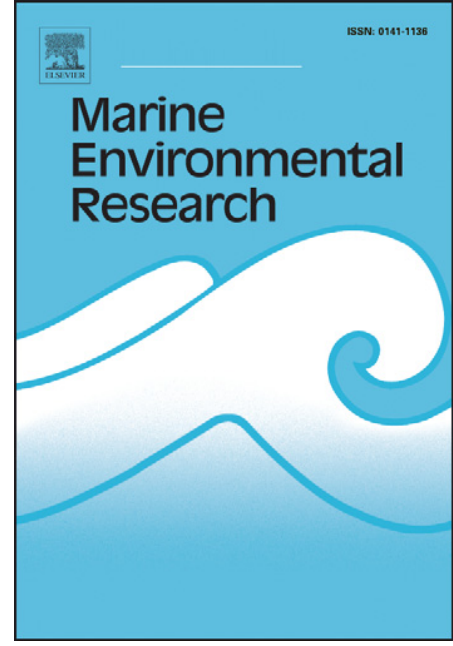

Received Date: $\quad 13$ February 2009

Revised Date: $\quad 12$ May 2009

Accepted Date: $\quad 15$ May 2009

Please cite this article as: Ward, J.E., Kach, D.J., Marine Aggregates Facilitate Ingestion of Nanoparticles by Suspension-Feeding Bivalves, Marine Environmental Research (2009), doi: 10.1016/j.marenvres.2009.05.002

This is a PDF file of an unedited manuscript that has been accepted for publication. As a service to our customers we are providing this early version of the manuscript. The manuscript will undergo copyediting, typesetting, and review of the resulting proof before it is published in its final form. Please note that during the production process errors may be discovered which could affect the content, and all legal disclaimers that apply to the journal pertain. 
J. Evan Ward* and Dustin J. Kach

Department of Marine Sciences University of Connecticut Groton, CT 06375

Phone: 860-405-9073, Fax: 869-405-9153

E-mail: evan.ward@uconn.edu 


\begin{abstract}
As the application of nanomaterials to science and technology grows, the need to understand any ecotoxicological effects becomes increasingly important. Recent studies on a few species of fishes and invertebrates have provided data which suggest that harmful effects are possible. The way in which nanoparticles are taken up by aquatic organisms, however, has been little studied. We examined uptake of nanoparticles by two species of suspension-feeding bivalves (mussels, Mytilus edulis; oysters, Crassostrea virginica), which capture individual particles $<1 \mu \mathrm{m}$ with a retention efficiency of $<15 \%$. Given this limitation, it would appear that nanoparticles could not be ingested in large numbers. During certain times of the year, however, $>70 \%$ of suspended particles are incorporated within aggregates that are $>100 \mu \mathrm{m}$ in size. Therefore, we delivered bivalves fluorescently labeled, 100-nm polystyrene beads that were either (1) dispersed or (2) embedded within aggregates generated in the laboratory. Results indicate that aggregates significantly enhance the uptake of $100-\mathrm{nm}$ particles. Nanoparticles had a longer gut retention time than $10-\mu \mathrm{m}$ polystyrene beads suggesting that nanoparticles were transported to the digestive gland. Our data suggest a mechanism for significant nanoparticle ingestion, and have implications for toxicological effects and transfer of nanomaterials to higher trophic levels.
\end{abstract}

Keywords: nanoparticles, blue mussel, eastern oyster, aggregates, ingestion 


\section{Introduction}

Manufactured nanoparticles (NPs) and nanotubes are at the forefront of nanotechnology and are being used in a variety of applications including cosmetics, electronics, drug delivery, manufacturing technologies, molecular biology, and paints (e.g., Harrison et al., 2000, Daniel and Astruc, 2004; Royal Society and Royal Academy, 2004; Kim et al. 2005; Engheta 2007; Schmid and Riediker, 2008). Nanomaterials with different compositions are being manufactured in increasing amounts, including those composed of carbon (e.g., single-walled nanotubes; fullerenes), germanium, transition metals (e.g., gold, palladium, platinum, silver), metal oxides (titanium dioxide, zinc oxide), polystyrene, and silica. Such widespread use will likely lead to their increased release into the environment, either directly via spills and use of products (direct emissions), or indirectly via landfills, waste incineration plants, and wastewater treatment facilities. Currently there are few data on environmental loads, but some estimates of use and release have been calculated. In Switzerland, 43 companies used quantities $>1000 \mathrm{~kg}_{\text {year }}{ }^{-1}$ per company (median quantity), with silver $(\mathrm{Ag})$, aluminum oxide $\left(\mathrm{Al}_{2} \mathrm{O}_{3}\right)$, iron oxides (e.g., $\left.\mathrm{Fe}_{2} \mathrm{O}_{3}\right)$, silicon dioxide $\left(\mathrm{SiO}_{2}\right)$, titanium dioxide $\left(\mathrm{TiO}_{2}\right)$, and zinc oxide $(\mathrm{ZnO})$ being the most commonly used NPs (Schmid and Riediker, 2008). In Australia, more than 300 registered sunscreen products contain either nanoscaled $\mathrm{TiO}_{2}$ or $\mathrm{ZnO}$ (Australian Gov., 2006). World-wide, some reports estimate that over 800 consumer products contain nanomaterials (Project on Emerging Nanotechnologies, 2008).

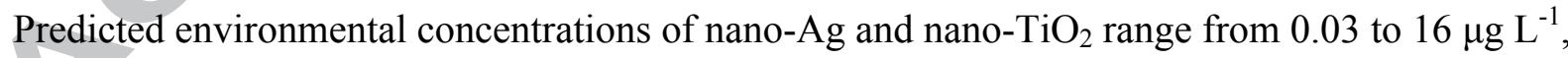
respectively (Mueller and Nowack, 2008). The concentration of $\mathrm{TiO}_{2} \mathrm{NPs}(20 \& 300 \mathrm{~nm})$ in runoff water that contacted painted facades was reported to be as high as $3.5^{*} 10^{8}$ particles $\mathrm{L}^{-1}$ (Kaegi et al., 2008). Actual transport and retention of NPs in soils and wastewater treatment plants likely depends on properties of the surrounding media, including $\mathrm{pH}$, ionic strength, and the concentration of organics and surfactants (LeCoanet et al., 2004; Limbach et al., 2008; Wang et al., 2008). 
Nonetheless, the above data suggest that freshwater and coastal environments are at risk of being contaminated with manufactured NPs because of their proximity to human populations, industry and wastewater discharge.

Most research on the ecotoxicity of NPs has focused on mammals, and various effects have been reported and debated (e.g., Colvin, 2003; Hoet et al., 2003; Lam et al., 2006; Handy and Shaw, 2007). Surface chemistry, physiochemical properties, and reactivity of NPs, as well as environmental factors, can affect interactions with cells and tissues (Sayes et al., 2004; Hardman, 2006). Even particles made of low-toxicity material (e.g., polystyrene, $\mathrm{TiO}_{2}$ ) can be harmful when delivered in their nano form, presumably due to the concomitantly high surface area (Oberdörster et al., 1994; Brown et al., 2001). Fewer studies have examined the effects of nanomaterials on aquatic organisms (Baun et al., 2008; Handy et al., 2008). Fullerenes $\left(\mathrm{C}_{60}\right)$ and single-walled carbon nanotubes have been shown to produce adverse effects on the water flea (Daphnia magna; Oberdörster et al., 2006; Roberts et al., 2007), zebrafish embryos (Zhu et al., 2007; Usenko et al., 2008), fathead minnow (Zhu et al., 2006), and rainbow trout (Smith et al., 2007). Using similar concentrations, however, other workers have found no effects of these nanomaterials on freshwater amphipods, harpactecoid copepods, or meiobenthic copepods (Oberdörster et al., 2006; Templeton et al., 2006). Nanoparticles containing metals (i.e., copper, gold, cadmium-telluride, silver) have also been shown to have deleterious effects on zebrafish (Griffitt et al., 2007; Asharani et al., 2008), on two species of daphnids (Griffitt et al., 2008), and on two species of bivalves (Gagńe et al., 2008; Tedesco et al., 2008). Nanoparticles of $\mathrm{TiO}_{2}$ and $\mathrm{ZnO}$ can be toxic to D. magna (Adams et al., 2006), and $\mathrm{TiO}_{2}$ NPs can cause oxidative stress in the rainbow trout (Federici et al., 2007). Additionally, because of their relatively high surface area, NPs are prime targets for adsorption and concentration of soluble pollutants such as arsenic (As), hydrocarbons, and metals (Cheng et al., 2004; Moore, 2006; Sun et al., 2007). Therefore, NPs have the potential to impact organisms 
directly through their inherent properties and also indirectly as a vehicle for other anthropogenic materials. Consequently, particulate material from nanotechnology is currently under scrutiny as a potential problematic anthropogenic pollutant (Hoet et al., 2003; Dreher, 2004; Royal Society and Royal Academy, 2004; Hardman, 2006; SCENIHR, 2006).

Although a growing number of studies are addressing the toxicity of manufactured nanomaterials on aquatic organisms, most have lacked an ecological and physiological approach. Almost nothing is known about the mode of uptake or ingestion rates of NPs, so the actual internal exposure concentration is unknown. This fact may explain some of the discrepancies in reported effects of NPs on aquatic organisms. Another gap in our current knowledge is the lack of data on organ retention times. Knowledge of these processes would provide valuable information on bioavailability of NPs and in vivo exposure times in the natural environment, and allow for more realistic toxicity studies. Additionally, for commercially harvested aquatic organisms such information is critical for an understanding of the potential transfer of NPs to humans.

In this study we examined the ingestion rate and egestion dynamics of polystyrene NPs by two species of bivalve molluscs. Suspension-feeding bivalves use their gills to capture particulate matter. Particles greater than ca. $6 \mu \mathrm{m}$ are captured with an efficiency $>90 \%$, whereas smaller particles are captured with an efficiency that decreases asymptotically with decreasing size (Riisgård, 1988). Although a few bivalve species can capture $1-\mu \mathrm{m}$ particles with $50 \%$ efficiency (e.g., Geukensia demissa), most species exhibit capture efficiencies of $<15 \%$ for particles $<1 \mu \mathrm{m}$ in size (Ward and Shumway, 2004; Kach and Ward, 2008). Given such limitations of the feeding organs, it would appear that bivalves would be at little risk of accumulating significant amounts of NPs. However, particulate material in aquatic environments rarely exists as individual particles. Physical and biological processes operate to aggregate particles into larger masses (Alldredge and Silver, 1988). At certain times of the year, a large proportion $(>70 \%)$ of natural particulates of 
varying size and quality can form aggregates mixed with high molecular weight substances (flocs, marine snow; Alldredge et al., 1993; Crocker and Passow, 1995). Flocculation of phytoplankton, detritus and other particles into rapidly sinking aggregates is an important mechanism of vertical transport of material to the benthos (Kiørboe et al., 1990; Passow and Wassmann, 1994; Crocker and Passow, 1995). The aggregate pathway can facilitate the trophic transfer of dissolved and microparticulate material to bivalves (Alber and Valiela, 1994, 1996; Kach and Ward, 2008). We propose that this pathway also increases accessibility of NPs.

\section{Materials and Methods}

\subsection{Production of aggregates}

Aggregates were produced in the laboratory following the method outlined by Shanks and Edmondson (1989). This roller-table method produces aggregates largely by differential settling, one of several physical mechanisms that cause particles to collide in aquatic systems. The procedures were modified slightly so that fluorescent NPs could be incorporated into the aggregates. Briefly, natural seawater was passed through a $210-\mu \mathrm{m}$ sieve to removed large zooplankton and particles. Polystyrene NPs (red fluorescent, $100 \mathrm{~nm}$; Thermo Fisher) were added to the seawater at a concentration of ca.1.3 $\times 10^{4}$ particles $\mathrm{ml}^{-1}$, along with $10 \mu \mathrm{g} \mathrm{l}^{-1}$ of hyaluronic acid, a carbohydrate polymer that enhanced aggregation. The suspension was transferred to $12,1-\mathrm{L}$ plastic bottles. Six of the bottles were then placed on a roller table at 15 RPM for 4 days. The other six bottles were placed next to the roller table to serve as controls (no aggregates). During the rolling period, water samples were taken from the 1-L bottles to follow incorporation of NPs into the aggregates. Incorporation was determined by allowing the aggregates in each rolled bottle to settle for $20 \mathrm{~min}$ and then taking a 20-ml sample from the center of the bottle. Bottles not being rolled were inverted three times, allowed to stand for $20 \mathrm{~min}$ and then sampled. The peak 
fluorescence (PF) of these samples was measured on a fluorescence spectrophotometer (Hitachi F2500; excitation $=303 \mathrm{~nm}$, emission $=610 \mathrm{~nm}$ ), and concentration of freely suspended NPs determined using a standard curve generated by measuring the fluorescence of known concentrations of NPs (see 2.4 below). Incorporation of NPs into aggregates was then determined by calculating the percent difference from the start concentration.

\subsection{Feeding Experiments}

We examined ingestion of NPs by two species of bivalves, the mussel (Mytilus edulis) and the oyster (Crassostrea virginica). These two species possess ctenidia with a unique combination of architecture and complexity of laterofrontal (LF) ciliary tracts, which aid in particle capture (Ward et al. 1998). Mussels (ca. $5.1 \mathrm{~cm}$ in shell length) and oysters (ca. $5.6 \mathrm{~cm}$ in shell height) were collected three days before experimentation and their outer shells scrubbed to remove living macro-organisms. Animals were then attached to wooden craft sticks using Velcro ${ }^{\circledR}$, so that they could be suspended in the experimental bottles. Using marine epoxy, one side of the Velcro ${ }^{\circledR}$ was secured to the shell and the other to a craft stick. Animals were maintained in flowing-seawater tables in the Rankin Laboratory on the Avery Point campus, University of Connecticut (Groton, CT, USA), until they were used in the experiments.

Experiments were conducted in an environmental chamber held at ca. $15^{\circ} \pm 0.5 \mathrm{C}$, a temperature consistent with ambient conditions measured in the holding tanks in the Rankin Laboratory. Two different experiments were conducted for each species. In experiment 1 , twelve individuals were used with six being exposed to NPs incorporated in aggregates and six to freely suspended NPs. In experiment 2, twelve individuals were exposed to NPs incorporated in aggregates and six to freely suspended NPs. For all experiments, each animal was introduced into either a bottle with aggregates or a bottle with NPs freely suspended (control), and its craft stick 
secured to the lip of the container with a wooden clip. A stir bar was added and the bottle placed on an electromagnetic stir plate. To ensure that aggregates and particles remained suspended, each bottle was supplied with gentle aeration and stirred for $10 \mathrm{sec}$ every $15 \mathrm{~min}$. Just prior to the start of a trial, $10-\mu \mathrm{m}$, non-fluorescent polystyrene beads were added to each bottle at a final concentration of 1000 beads $\mathrm{ml}^{-1}$. These beads were in the size range that could be captured by each species with an efficiency of about $100 \%$, allowing for the quantification of feeding rates. Additionally, two animals of each species were delivered only $10-\mu \mathrm{m}$, non-fluorescent beads and served as experimental blanks. Animals were allowed to feed for $45 \mathrm{~min}$, with start times beginning when the individual animal opened its shell and appeared to be feeding (siphons or mantle extended).

\subsection{Feces collection and preparation}

Egestion dynamics were investigated after the exposure to NPs. Animals were removed from the bottles and placed in individual, 1-L beakers filled with filtered seawater. For experiment 1, all feces produced over the next 72 hours were collected from each animal and placed in separate vials. For experiment 2, separate fecal collections were made for three animals after $6,24,48$ and 72 hours (individuals of each species being sacrificed at each time interval). Again, feces from each individual were placed in a separate vial. These samples served as a time series for egestion. The microalga Tetraselmis sp. was added to each beaker (final concentration $=\mathrm{ca} .1 \times 10^{4}$ cells $\mathrm{ml}^{-1}$ ) after 24 and 48 hours to stimulate transit of material through the digestive tract. The collected fecal samples were placed in individual, 15-ml falcon tubes and centrifuged for 10 minutes at $1320 \mathrm{rcf}$ (g). The seawater supernatant was decanted and the pellet resuspended in $6 \mathrm{ml}$ of deionized water (DI), spun for another ten minutes, and again decanted. This washing process was repeated two additional times to remove salts which react with sodium hydroxide $(\mathrm{NaOH})$ to form a precipitate. After the final wash, $2.0 \mathrm{ml}$ of $1 \mathrm{~N} \mathrm{NaOH}$ were added to each tube. Digestive-gland samples were 
patted with laboratory tissue, dried in a desiccator and weighed. Samples were placed in individual falcon tubes and treated with $2.0 \mathrm{ml}$ of $1 \mathrm{~N} \mathrm{NaOH}$. The fecal and digestive-gland samples were then sonicated for five minutes, resuspended by means of a Vortex Genie ${ }^{\circledR}$ and allowed to digest for seven days. Samples were then diluted with $6.0 \mathrm{ml}$ of DI water to bring the total volume of each to ca. $8.0 \mathrm{ml}$.

\subsection{Spectrophotometric analysis}

Material in each falcon tube was re-suspended and a 2.0-ml sub-sample removed. The peak fluorescence (PF) of each sub-sample was measured by means of a fluorescent spectrophotometer (excitation $=304 \mathrm{~nm}$, emission $=610 \mathrm{~nm})$, and the concentration of NPs determined using a standard curve. The 9-point, linear standard curve was generated by suspending known numbers of NPs in a fixed volume of DI water and determining PF on the fluorescent spectrophotometer. To confirm the accuracy of the equations, feces and digestive glands were obtained from animals not used in the experiments and digested in $\mathrm{NaOH}$. Known numbers of NPs were suspended in the resulting liquid and analyzed.

Total number of NPs egested was then calculated for each animal, and ingestion rates estimated by dividing by the pumping rate of the individual. To calculate pumping rate, a 1-ml subsample was removed from each falcon tube and the number of $10-\mu \mathrm{m}$ beads (non-fluorescent) counted on a hemocytometer. The total number of beads egested represents the total number ingested. As these beads could be captured at about 100\% efficiency (Møhlenberg and Riisgård, 1978; Riisgård, 1988), pumping rate (PR) could be calculated using the following equation (Kach and Ward, 2008):

$$
\left.\operatorname{PR}\left(\mathrm{ml} \mathrm{h}^{-1}\right)=\left[\text { beads ingested (No.) / initial bead concentration (No. } \mathrm{ml}^{-1}\right)\right] / \text { time }(\mathrm{h})
$$




\section{Results}

Visible aggregates ranging in size from $>100 \mu \mathrm{m}$ to several $\mathrm{mm}$ always formed in the rolled bottles. No such aggregates formed in the bottles that were not rolled, although some nanoparticle loss did occur $(<2.5 \%)$. Additionally, data from preliminary trials indicated that some NPs $(<$ $1.8 \%$ ) adhered to the sides of rolled bottles. Therefore, incorporation of NPs into aggregates was adjusted for these minor losses. For all experiments, the efficiency at which NPs were incorporated into aggregates ranged from 52 to $64 \%$. Visual inspection of our laboratory-produced aggregates showed that they differed little from natural aggregates in size and shape (see Kach and Ward, 2008). These observations corroborate the study of Shanks and Edmondson (1989) who demonstrated that aggregates produced on a roller table were a good representation of natural aggregates.

Both species of bivalves ingested NPs at a significantly higher rate when particles were incorporated in aggregates compared to when they were freely suspended (2-way ANOVA, GLM, $p$ $<0.01$; Fig. 1). In fact, the number of freely suspended NPs ingested by the bivalves was so low that no fluorescent activity could be detected. Pumping rate, however, for mussels in both treatments (aggregate $=0.360 \pm 0.018 \mathrm{~L} \mathrm{hr}^{-1}$; no aggregate $=0.356 \pm 0.018 \mathrm{~L} \mathrm{hr}^{-1}$ ) and oysters in both treatments (aggregate $=0.319 \pm 0.014 \mathrm{~L} \mathrm{hr}^{-1}$; no aggregate $=0.326 \pm 0.010 \mathrm{~L} \mathrm{hr}^{-1}$ ) were similar. For the aggregate treatment, mussels ingested NPs at a significantly higher rate than oysters (Bonferroni multiple comparison, $\mathrm{p}<0.01$ ).

For both species of bivalves, egestion of $10-\mu \mathrm{m}$ beads over time displayed an opposite trend compared to egestion of NPs over time (Fig. 2). Whereas the highest number of $10-\mu \mathrm{m}$ beads was egested after 6 hours, the highest number of NPs was egested after 72 hours. Number of $10-\mu \mathrm{m}$ beads egested decreased over time, whereas number of NPs egested increased over time. No fluorescence was detected in fecal samples from the experimental blanks. 


\section{Discussion}

Our data clearly indicate that mussels and oysters more efficiently capture and ingest NPs that are incorporated into aggregates compared to those freely suspended. As reported for mucusbound food material (Ward et al., 1993; Ward et al., 1994), aggregates are likely broken down by the action of cilia on the gills and labial palps and the constituent particles ingested. Some aggregated material is likely to be rejected as pseudofeces, but our results demonstrate that a large fraction is ingested. Time series experiments show that polystyrene NPs have a longer gut retention time (GRT) compared to $10-\mu \mathrm{m}$ polystyrene particles. Previously studies report that $>85 \%$ of $>5$ $\mu \mathrm{m}$ polystyrene, silica, and aluminum beads are often egested after ca. $30 \mathrm{~h}$ (Ward and Target, 1989; Cranford et al., 1998; Brillant and MacDonald, 2002). Bivalves are capable of particle selection in the gut (Brillant and MacDonald, 2000, 2002, 2003), and longer GRT for food usually indicates that the material has undergone more extensive extracellular digestion and, perhaps, been transported to the digestive glands for more complete intracellular digestion. In the present case, the longer GRT suggests that most NPs were directed into the tubules of the digestive glands and potentially taken up by the digestive cells via endocytosis. Sucrose-polyester NPs can be taken up by isolated digestive-gland cells of blue mussels (Mytilus edulis) and by whole animals (Moore et al., 1997). Cadmium-telluride quantum dots can produce cellular damage in the digestive gland of the freshwater bivalve Elliption complanata (Gagne et al., 2008), and $\mathrm{Au}$ and $\mathrm{SiO}_{2} \mathrm{NPs}$ can produce harmful effects in the digestive gland of M. edulis (Koehler et al., 2008; Tedesco et al. 2008). Our data from analysis of the digestive gland and gut confirm the presence of fluorescent NPs in these tissue 72 hours after the experiments. Consequently, the calculated ingestion rates of NPs should be considered minimal values. 
Results of the present study have implications for experimental as well as natural exposure of bivalves to NPs. In laboratory assays that expose bivalves to a known concentration of freely suspended NPs, the uptake and thus bioavailability of these particles will be very low. Even aggregates of NPs up to $0.5 \mu \mathrm{m}$ will have a low bioavailability (Kach and Ward 2008). Although some particles could perhaps be taken up across the epithelium of the gill, mantle and labial palps (Kashiwada, 2006; Koehler et al., 2008), the major route for internal exposure and potential effects is via capture and ingestion. Consequently, the actual exposure levels will likely be much lower than those calculated based on mass or number per volume of water delivered to the animals. In fact, actual uptake will be a consequence of at least two factors: 1) the form in which the NPs are delivered (e.g., monodisperesed, slightly aggregated, highly aggregated), and 2) the capture efficiency of the particular bivalve species for the delivered particle masses (e.g., nanoparticle masses $<5 \mu \mathrm{m}$ will be captured and ingested with different efficiencies). These factors need to be quantified for each experiment to allow comparison of results among studies that utilized bivalves. For example, of the several studies that have examined the effects of manufactured NPs on bivalves (Koehler et al., 2008; Tedesco et al., 2008), only Gagńe et al. (2008) mention that aggregation of particles occurred. In this study, the authors indicate that cadmium-telluride quantum dots tended to aggregate at medium $\left(4 \mathrm{mg} \mathrm{L}^{-1}\right)$ and high $\left(8 \mathrm{mg} \mathrm{L}^{-1}\right)$ concentrations. If so, then the aggregated quantum dots probably were ingested by freshwater mussels at a higher rate than those not aggregated (i.e., at $1.6 \mathrm{mg} \mathrm{L}^{-1}$ ). Thus, the dose-response trend observed by Gagńe et al. (2008) could have been confounded by the possibility that quantum dots at higher concentrations were more available to mussels over the experimental period.

Under natural conditions, self-aggregation of NPs into larger particle masses and incorporation of NPs into aggregated material will increase the bioavailability to suspension-feeding bivalves. The adsorption of organic material by NPs can alter their physiochemical properties and 
lead to enhanced aggregation (Brant et al., 2005; Moreau et al., 2007; Li et al., 2008; Xie et al., 2008). Not only would incorporation of NPs into aggregates enhance uptake and internal exposure, but aggregates would tend to sink faster than their constituent NPs (Kriest and Evans, 1999; Waite et al., 2000). Higher sinking rates would increase the flux of NPs to the benthos, exposing suspension and deposit feeders to a large concentration of these materials. Additionally, nanomaterials are thought to be persistent in the environment (e.g., SCENIHR, 2006), so resuspension events, such as storms, could re-expose bivalves to previously deposited NPs, causing spikes of uptake and accumulation.

\section{Conclusion}

The promise of nanomaterials for science, technology and the economy is great, but the ecotoxicological effects and pathological risks to animals and humans may be equally large (Colvin, 2003; Royal Society and Royal Academy of Engineering, 2004). In order to define the effects of nanoparticle exposure on benthic organisms and develop reliable biomarkers, the uptake and ingestion dynamics by benthic animals, and visceral mass retention times need to be determined. Evaluating the environmental risk of these materials will require knowledge of the concentrations in the environment as well as the form in which they exist (e.g., dispersed, attached to particles, incorporated in aggregates) and their distribution in the pelagic vs benthic realms.

Bivalves are ideal sentinel organisms because they process large volumes of water per unit time (e.g., 3-9 L h ${ }^{-1}$ g dry mass ${ }^{-1}$; Newell et al., 2005). The amount of suspended material removed, however, is a function of particle size and retention efficiency of the particular species. The aggregate pathway can facilitate the trophic transfer of dissolved and microparticulate material to bivalves (Alber and Valiella, 1994, 1996; Kach and Ward, 2008), and we have demonstrated that this pathway can also significantly enhance the ingestion of NPs. Our findings have implications 
for the accumulation of NPs in bivalves, and the transfer to higher trophic levels including humans. Future studies should examine the incorporation rates of NPs into marine aggregates, as well as the uptake dynamics of nanoparticle-laden aggregates by suspension and deposit feeding animals in order to better understand the impacts of these materials on aquatic ecosystems.

\section{Acknowledgements}

We thank Bridget Holohan, Jeff Godfrey, and Jim Markow (Noank Shellfish Cooperative) for help with various aspects of this study. This research was funded by grants from the National Science Foundation (USA) to J.E.W. and others (DBI-FSML 990-7701, EF-0429-004). 


\section{References}

Adams, L.K., Lyon, D.Y., McIntosh, A., Alvarez, P.J.J., 2006. Comparative toxicity of nano-scale $\mathrm{TiO}_{2}, \mathrm{SiO}_{2}$ and $\mathrm{ZnO}$ water suspensions. Water Science and Technology 54, 327-334.

Alber, M., Valiela, I., 1994. Incorporation of organic aggregates by marine mussels. Marine Biology 121, 259-265.

Alber, M., Valiela, I., 1996. Utilization of microbial organic aggregates by bay scallops, Argopecten irradians (Lamarck). Journal of Experimental Marine Biology and Ecology 195, 71-89.

Alldredge A.L., Silver, M.W., 1988. Characteristics, dynamics and significance of marine snow. Progress in Oceanography 20, 41-82.

Alldredge, A.L., Passow, U., Logan, B.E., 1993. The abundance and significance of a class of large, transparent organic particles in the ocean. Deep-Sea Research 40, 1131-1140.

Asharani, P.V., Wu, Y.L., Gong, Z., Valiyaveettil, S., 2008. Toxicity of silver nanoparticles in zebrafish models. Nanotechnology 19, 255102.

Australian Government, 2006. Safety of Sunscreens Containing Nanoparticles of Zinc Oxide or Titanium Dioxide. http://www.tga.gov.au/npmeds/sunscreen-zotd.htm.

Baun, A., Hartmann, N.B., Grieger, K., Kusk, K.O., 2008. Ecotoxicity of engineered nanoparticles to aquatic invertebrates: a brief review and recommendations for future toxicity testing. Ecotoxicology 17, 387-395.

Brant, J., Lecoanet, H., Wiesner, M.R., 2005. Aggregation and deposition characteristics of fullerene nanoparticles in aqueous systems. Journal of Nanoparticle Research 7, 545-553.

Brillant, M.G.S., MacDonald, B.A., 2000. Postingestive selection in the sea scallop, Placopecten magellanicus (Gmelin): the role of particle size and density. Journal of Experimental Marine Biology and Ecology 253, 211-227. 
Brillant, M.G.S., MacDonald, B.A., 2002. Postingestive selection in the sea scallop (Placopecten magellanicus) on the basis of chemical properties of particles. Marine Biology 141, 457-465.

Brillant, M.G.S., MacDonald, B.A., 2003. Postingestive sorting of living and heat-killed Chlorella within the sea scallop, Placopecten magellanicus (Gmelin). Journal of Experimental Marine Biology and Ecology 290, 81-91.

Brown, D.M., Wilson, M.R., MacNee, W., Stone, V., Donaldson, K., 2001. Size-dependent proinflammatory effects of ultrafine polystyrene particles: a role for surface area and oxidative stress in the enhanced activity of ultrafines. Toxicology and Applied Pharmacology 175, 191199.

Cheng, X.K., Kan, A.T., Tomsom, A.B., 2004. Naphthalene adsorption and desorption from aqueous C-60 fullerene. Journal of Chemical and Engineering Data 49, 675-683.

Colvin, V.L., 2003. The potential environmental impact of engineered nanomaterials. Nature Biotechnology 21, 1166-1170.

Cranford, P.J., Emerson, C.W., Hargrave, B.T., Milligan, T.G., 1998. In situ feeding and absorption responses of sea scallops Placopecten magellanicus (Gmelin) to storm-induced changes in the quantity and composition of the seston. Journal of Experimental Marine Biology and Ecology $219,45-70$.

Crocker, K. M., Passow, U., 1995. Differential aggregation of diatoms. Marine Ecology Progress Series 117, 249-257.

Daniel, M.C., Astruc, D., 2004. Gold nanoparticles: Assembly, supramolecular chemistry, quantumsize-related properties, and applications toward biology, catalysis, and nanotechnology. Chemical Reviews 104, 293-346.

Dreher K.L., 2004. Health and environmental impact of nanotechnology: toxicological assessment of manufactured nanoparticles. Toxicological Sciences 77, 3-5. 
Engheta, N., 2007. Circuits with light at nanoscales: Optical nanocircuits inspired by metameterials. Science $317,1698-1702$.

Federici, G., Shaw, B.J., Handy, R.D., 2007. Toxicity of titanium dioxide nanoparticles to rainbow trout (Oncorhynchus mykiss): gill injury, oxidative stress and other physiological effects. Aquatic Toxicology 84, 415-430.

Gagné, F., Auclair, J., Turcotte, P., Fournier, M., Gagnon, C., Sauvé, S., Blaise, C., 2008. Ecotoxicity of CdTe quantum dots to freshwater mussels: Impacts on immune system, oxidative stress and genotoxicity. Aquatic Toxicology 86:333-340.

Griffitt, R.J., Weil, R., Hyndman, K.A., Denslow, N.D., Powers, K., Taylor, D., Barber, D.S., 2007. Exposure to copper nanoparticles causes gill injury and acute lethality in zebrafish (Danio rerio). Environmental Science and Technology 41, 8178-8186.

Griffitt, R.J., Luo, J., Gao, J., Bonzonga, J-C., Barber, D.S., 2008. Effects of particle composition and species on toxicity of metallic nanomaterials in aquatic organisms. Environmental Toxicology and Chemistry 27, 1972-1978.

Handy, R.D., Shaw, B.J., 2007. Toxic effects of nanoparticles and nanomaterials: implications for public health, risk assessment and the public perception of nanotechnology. Health Risk and Society $9,125-144$.

Handy, R.D., von der Kammer, F., Lead, J.R., Hassellöv, M., Owen, R., Crane, M., 2008. The ecotoxicology and chemistry of manufactured nanoparticles. Ecotoxicology 17, 287-314.

Hardman R., 2006. A toxicologic review of quantum dots: toxicity depends on physiochemical and environmental factors. Environmental Health Perspectives 114, 165-172.

Harrison, M.T., Kershaw, S.V., Burt, M.G., Rogach, A.L., Kornowski, A., Eychmüller, A., Weller, H., 2000. Colloidal nanocrystals for telecommunications. Complete coverage of the low-loss fiber windows by mercury telluride quantum dots. Pure and Applied Chemistry 72, 295-307. 
Hoet, P.H.M., Nemmar, A., Nemery, B., 2003. Health impact of nanomaterials. Nature Biotechnology 22, 19.

Kaegi, R., Ulrich, A., Sinnet, B., Vonbank, R., Wichser, A., Zuleeg, S., Simmler, H., Brunner, S., Vonmont H., Burkhardt, M., Boller, M., 2008. Synthetic $\mathrm{TiO}_{2}$ nanoparticle emission from exterior facades into the aquatic environment. Environmental Pollution 156, 233-239.

Kach, D.J., Ward, J.E., 2008. The role of marine aggregates in the ingestion of picoplankton-size particles by suspension-feeding molluscs. Marine Biology 153, 797-805.

Kashiwada, S., 2006. Distribution of nanoparticles in the see-through medaka (Oryzias latipes). Environmental Health Perspectives 114, 1697-1702.

Kim, D., El-Shall, H., Dennis, D., Morey, T., 2005. Interaction of PLGA nanoparticles with human blood constituents. Colloids Surf B: Biointerfaces 40, 83-91.

Kiørboe, T., Andersen, K.P., Dam, H.G., 1990. Coagulation efficiency and aggregate formation in marine phytoplankton. Marine Biology 107, 235-245.

Koehler, A., Marx, U., Broeg, K., Bahns, S., Bressling, J., 2008. Effects of nanoparticles in Mytilus edulis gill and hepatopancreas - A new threat to marine life? Marine Environmental Research $66,12-14$.

Kriest, I., Evans, G.T., 1999. Representing phytoplankton aggregates in biogeochemical models. Deep-Sea Research 46, 1841-1859.

Lam C-W., James, J.T., McCluskey, R., Arepalli, S., Hunter, R.L., 2006. A review of carbon nanotube toxicity and assessment of potential occupational and environmental health risks. Critical Reviews in Toxicology 36, 189-217.

LeCoanet, H., Bottero, J.-Y., Wiesner, M.R., 2004. Laboratory Assessment of the Mobility of nanomaterials in porous media. Environmental Science and Technology 38, 5164-5169. 
Li, B., Ward, J.E., Holohan, B.A., 2008. Transparent exopolymer particles (TEP) from marine suspension feeders enhance particle aggregation. Marine Ecology Progress Series 357, 67-77.

Limbach, L., Bereiter, R., Müller, E., Krebs, R., Gälli, R., Stark, W.J., 2008. Removal of oxide nanoparticles in a model wastewater treatment plant: Influence of agglomeration and surfactants on clearing efficiency. Environmental Science and Technology 42, 5828-5833. Møhlenberg, F., Riisgård, H.U., 1978. Efficiency of particle retention in 13 species of suspension feeding bivalves. Ophelia 17, 239-246.

Moore, M.N., 2006. Do nanoparticles present ecotoxicological risks for the health of the aquatic environment? Environmental International 32, 967-976.

Moore, M.N., Lowe, D.M., Soverchia, C, Haigh, S.D., Hales, S.G., 1997. Uptake of non-calorific, edible sucrose polyester oil and olive oil by marine mussels and their influence on uptake and effects of anthracene. Aquatic Toxicology 39, 307-320.

Moreau, J.W., Weber, P.K., Martin, M.C., Gilbert, B., Hutcheon, I.D., Banfield J.F., 2007. Extracellular proteins limit the dispersal of biogenic nanoparticles. Science 316, 1600-1603.

Mueller, N., Nowack, B., 2008. Exposure modeling of engineered nanoparticles in the environment. Environmental Science and Technology 42, 4447-4453.

Newell, R.I.E., Fisher, T.R., Holyoke, R.R., Cornwell, J.C., 2005. Influence of eastern oysters on nitrogen and phosphorus regeneration in Chesapeake Bay, USA, in: Dame, R.F., Olenin, S. (Eds), The Comparative Roles of Suspension-Feeders in Ecosystems. Springer, Dordrecht, The Netherlands, pp. 93-120.

Oberdörster, G., Ferin, J., Lehnert, B.E., 1994. Correlation between particle size, in vivo particle persistence, and lung injury. Environmental Health Perspectives 102, 173-179. 
Oberdörster, E., Zhu, S., Blickley, T.M., McClellan-Green, P., Haasch, M.L., 2006. Ecotoxicology of carbon-based engineered nanoparticles: Effects of fullerene $\left(\mathrm{C}_{60}\right)$ on aquatic organisms. Carbon 44, 1112-1120.

Passow, U., Wassmann, P., 1994. On the trophic fate of Phaeocystis pouchetii (Hariot). 4. The formation of marine snow by P. pouchetii. Marine Ecology Progress Series 104, 153-161. Project on Emerging Nanotechnologies, 2008. Woodrow Wilson International Center for Scholars and the Pew Charitable Trusts, www.nanotechproject.org/inventories/consumer www.

Riisgård, H.U., 1988. Efficiency of particle retention and filtration rate in 6 species of northeast American bivalves. Marine Ecology Progress Series 45, 217-223.

Roberts, A.P., Mount, A.S., Seda, B., Souther, J., Qiao, R., Lin, S., Ke, P.C., Rao, A.M., Klaine, S.J., 2007. In vivo biomodification of lipid-coated carbon nanotubes by Daphnia magna. Environmental Science and Technology 41, 3025-3029.

Royal Society and Royal Academy of Engineering, 2004. Nanoscience and nanotechnologies: opportunities and uncertainties. Royal Society Policy Document 19/04, London, The Royal Society, $113 \mathrm{pp}$.

Sayes, C.M., Fortner, J.D., Guo, W., Lyon, D., Boyd, A.M., Ausman, K.D., Tao, Y.J., Sitharaman, B., Wilson, L.J., Hughes, J.B., West, J.L., Colvin, V.L., 2004. The differential cytotoxicity of water soluble fullerenes. Nanolettters 4, 1881-1887.

SCENIHR, Scientific Committee on Emerging and Newly Identified Health Risks, 2006. The appropriateness of existing methodologies to assess the potential risks associated with engineered and adventitious products of nanotechnologies. European Commission Health \& Consumer Protection Directorate-General, 79 pp.

Schmid, K., Riediker, M., 2008. Use of nanoparticles in Swiss industry: A targeted survey. Environmental Science and Technology 42, 2253-2260. 
Shanks A.L., Edmonson, E.W., 1989. Laboratory-made artificial marine snow: a biological model of the real thing. Marine Biology 101, 463-470.

Smith, C.J., Shaw, B.J., Handy, R.D., 2007. Toxicity of single walled carbon nanotubes to rainbow trout, (Oncorhynchus mykiss): Respiratory toxicity, organ pathologies, and other physiological effects. Aquatic Toxicology 82, 94-109.

Sun, H., Zhang, X., Niu, Q., Chen, Y., Crittenden, J.C., 2007. Enhanced accumulation of arsenate in carp in the presence of titanium dioxide nanoparticles. Water Air and Soil Pollution 178, 245254.

Tedesco, S., Doyle, H., Redmond, G., Sheehan, D., 2008. Gold nanoparticles and oxidative stress in Mytilus edulis. Marine Environmental Research 66, 131-133.

Templeton, R.C., Ferguson, P.L., Washburn, K.M., Scrivens, W.A., Chandler, G.T., 2006. Lifecycle effects of single-walled carbon nanotubes (SWNTs) on an estuarine meiobenthic copepod. Environmental Science and Technology 40, 7387-7393.

Waite, A.M., Safi, K.A., Hall, J.A., Nodder, S.D., 2000. Mass sedimentation of picoplankton embedded in organic aggregates. Limnology and Oceanography 45, 87-97.

Wang, Y., Li, Y., Fortner, J.D., Hughes, J.B., Abriola, L., Pennell, K.D., 2008. Transport and retention of nanoscale $\mathrm{C}_{60}$ aggregates in water-saturated porous media. Environmental Science and Technology 42, 3588-3594.

Ward, J.E., Shumway, S.E., 2004. Separating the grain from the chaff: Particle selection in suspension- and deposit-feeding bivalves. Journal of Experimental Marine Biology and Ecology 300, 83-130.

Ward, J.E., Targett, N.M., 1989. Are metabolites from the brown tide alga, Aureococcus anophagefferens, deleterious to mussel feeding behavior? in: Cosper, E.M., Bricelj, V.M., 
Carpenter, E.J. (Eds.), Coastal and Estuarine Studies, No. 35. Novel Phytoplankton Blooms, Springer-Verlag, New York, pp. 543-556.

Ward, J.E., MacDonald, B.A., Thompson, R.J., Beninger, P.G., 1993. Mechanisms of suspensionfeeding in bivalves: resolution of current controversies by means of endoscopy. Limnology and Oceanography 38, 265-272.

Ward, J.E., Newell, R.I.E., Thompson, R.J., MacDonald, B.A., 1994. In vivo studies of suspensionfeeding processes in the oyster Crassostrea virginica (Gmelin). Biological Bulletin 186, 221 240.

Ward, J.E., Sanford, L.P., Newell, R.I.E., MacDonald, B.A., 1998. A new explanation of particle capture in suspension-feeding bivalve molluscs. Limnology and Oceanography 43, 741-752.

Xie, B., Xu, Z., Guo, W., Li, Q., 2008. Impact of natural organic matter on the physicochemical properties of aqueous $\mathrm{C}_{60}$ nanoparticles. Environmental Science and Technology 42, 28532859.

Zhu, S., Oberdörster, E., Haasch, M.L., 2006. Toxicity of an engineered nanoparticle (fullerene, $\mathrm{C}_{60}$ ) in two aquatic species, Daphnia and fathead minnow. Marine Environmental Research 62, S5-S9.

Zhu, X., Zhu, L., Li, Y., Duan, Z., Chen, W., Alvarez, P.J.J., 2007. Developmental toxicity in zebrafish (danio rerio) embryos after exposure to manufactured nanomaterials: Buckminsterfullerene aggregates $\left(\mathrm{nC}_{60}\right)$ and fullerol. Environmental Toxicology and Chemistry 26, 976-979. 


\section{Figure captions}

Figure 1. Ingestion rate of polystyrene nanoparticles (NPs, $100 \mathrm{~nm}$ ) by the mussel (Mytilus edulis) and oyster (Crassostrea virginica). For both species, aggregate-bound NPs were ingested at a significantly higher rate than freely suspended NPs (no aggregates). Mussels ingested aggregatebound NPs at a significantly higher rate than oysters. Bars with different letters are significantly different at $\mathrm{p}<0.01$. Data are means $\pm \mathrm{SD}$ for 6 replicate animals. $\mathrm{ND}=$ not detected.

Figure 2. Egestion of polystyrene nanoparticles (NPs, $100 \mathrm{~nm}$ ) and $10-\mu \mathrm{m}$ beads by $\mathbf{A}$. the mussel (Mytilus edulis), and B. the oyster (Crassostrea virginica). Both particle types were delivered to bivalves at the same time, but NPs were incorporated in aggregates. Notice that egestion of $10-\mu \mathrm{m}$ beads decreases with time whereas egestion of NPs increases with time. End point for NP egestion was not reached. Data are means $\pm \mathrm{SD}$ for $12,9,6$, and 3 replicate animals at times $6,24,48$ and 72 hours, respectively. ND = not detected. 


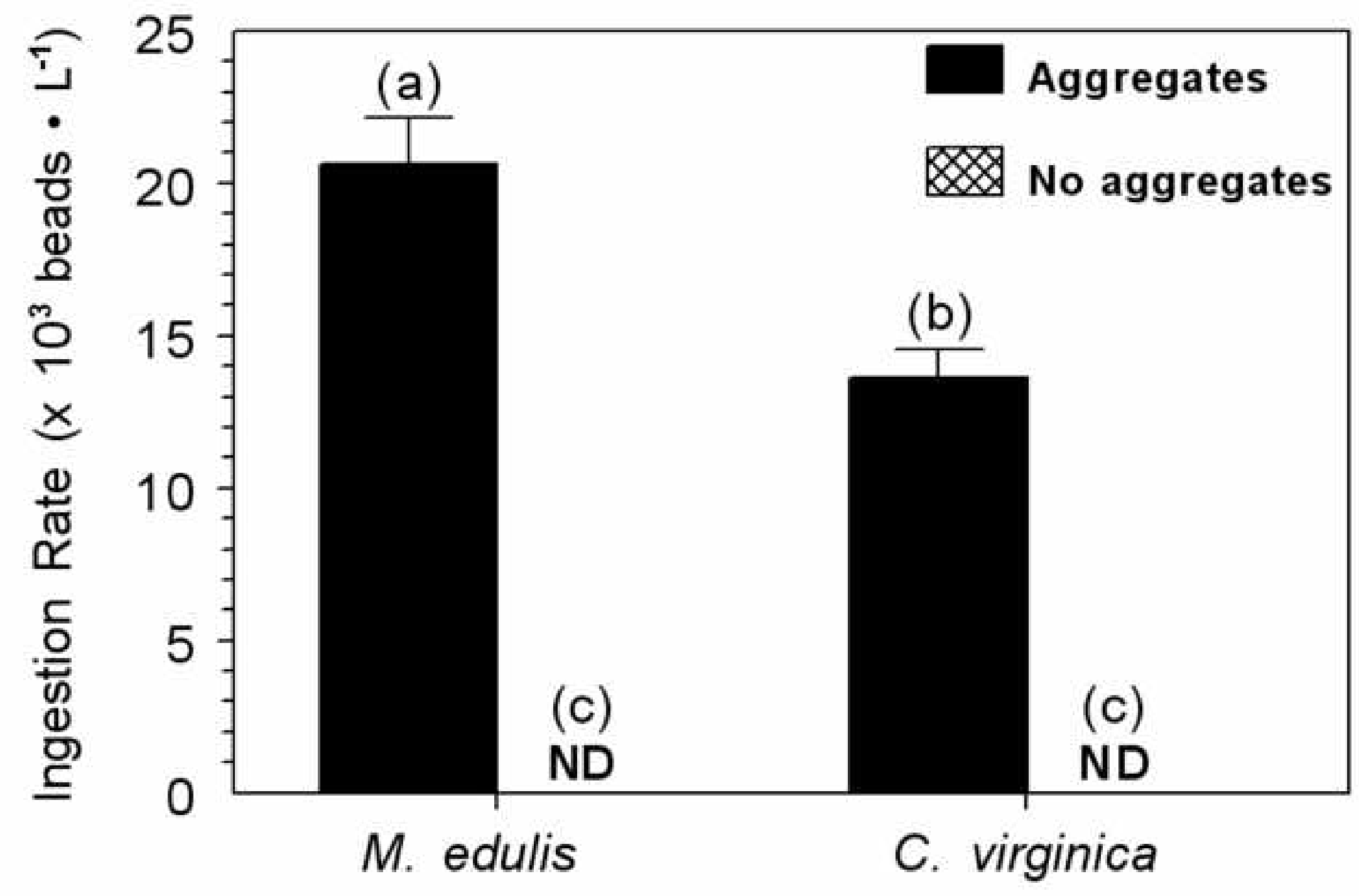




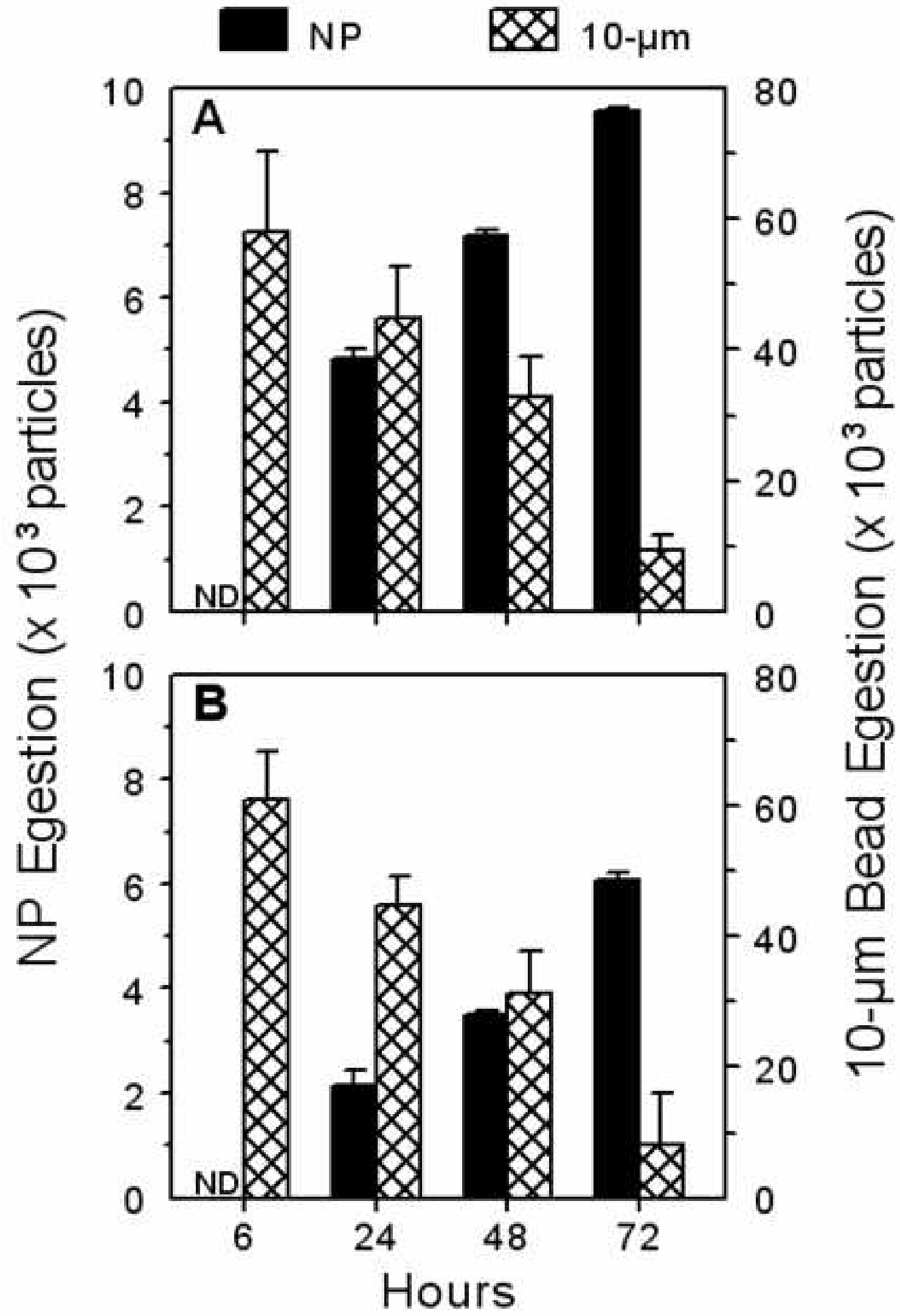

